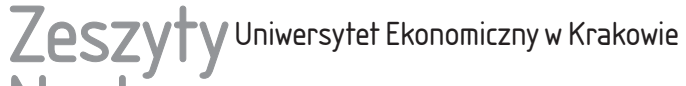 Naukowe
}

$11(959)$

ISSN 1898-6447

Zesz. Nauk. UEK, 2016; 11 (959): 93-108

DOI: 10.15678/ZNUEK.2016.0959.1106

\section{Analiza porównawcza modeli systemów ratownictwa w Polsce i w wybranych krajach*}

\section{Streszczenie}

Systemy ratownictwa gwarantują bezpieczeństwo oraz właściwy poziom ochrony ludności. Jednym z przedsięwzięć ukierunkowanych na rozwój systemów ratownictwa jest ich ciągłe doskonalenie oraz wzbogacanie przez wykorzystanie specjalistycznych metod i narzędzi. Odpowiedni dobór nowych metod i narzędzi powinien być poprzedzony wnikliwą analizą obecnie funkcjonujących systemów w kraju i na świecie. Celem artykułu jest przedstawienie wybranych zagranicznych rozwiązań w zakresie ratownictwa, które zdaniem autorów warto włączyć do krajowego systemu ratownictwa. Wskazane rozwiązania są rekomendowane na podstawie analizy krajowego systemu ratownictwa i systemów działających w innych krajach.

Słowa kluczowe: system ratownictwa, model systemu ratownictwa, analiza statystyk, analiza SWOT, rekomendacje.

Klasyfikacja JEL: H12, O21.

Grzegorz Kunikowski, Politechnika Warszawska, Wydział Zarządzania, Katedra Systemów Zarządzania, ul. Narbutta 85, 02-524 Warszawa, e-mail: Grzegorz.Kunikowski@pw.edu.pl

Katarzyna Rostek, Politechnika Warszawska, Wydział Zarządzania, Katedra Systemów Zarządzania, ul. Narbutta 85, 02-524 Warszawa, e-mail: Katarzyna.Rostek@pw.edu.pl

* Przeprowadzone badania miały charakter studialny i są częścią projektu Narodowego Centrum Badań i Rozwoju pn. „Wysokospecjalistyczna platforma wspomagająca planowanie cywilne i ratownictwo w administracji publicznej Rzeczypospolitej Polskiej oraz w jednostkach organizacyjnych Krajowego Systemu Ratowniczo-Gaśniczego". Uzyskane wyniki zostaną wykorzystane do budowy wysokospecjalistycznej platformy wspomagającej planowanie cywilne i ratownictwo w jednostkach administracji publicznej. 


\section{Wprowadzenie}

Podstawowe znaczenie dla skutecznej ochrony ludności stanowi zdolność państwa do zapewnienia właściwej pomocy medycznej oraz udzielania doraźnej pomocy ratowniczej w sytuacjach zagrożeń. Za pierwszą z tych funkcji odpowiada państwowy system ratownictwa medycznego (PRM), którego działalność jest określona w ustawie o Państwowym Ratownictwie Medycznym [Ustawa z dnia 8 września 2006...]. Funkcję drugą realizuje Krajowy System Ratowniczo-Gaśniczy (KSRG), wspierany przez ochotnicze straże pożarne (OSP) oraz wiele społecznych organizacji ratowniczych (w tym obronę cywilną). Funkcjonowanie KSRG zostało z kolei określone ustawą o ochronie przeciwpożarowej [Ustawa z dnia 24 sierpnia 1991...]. Istotną rolę w komunikacji pomiędzy osobami potrzebującymi pomocy a służbami ratowniczymi odgrywa System Powiadamiania Ratunkowego (SPR). Jego zadaniem jest pośredniczenie pomiędzy obywatelem a podmiotami ratowniczymi oraz monitorowanie rozwoju sytuacji, tak aby w razie potrzeby angażować do działania niezbędne podmioty towarzyszące (służby, inspekcje, straże).

Wspólną cechą wymienionych powyżej systemów ratowniczych jest gotowość i ciągłość działania (24 godziny przez 7 dni w tygodniu) w odniesieniu do osób potrzebujących pomocy w każdej sytuacji. Różnice w ich funkcjonowaniu zależą od skali zagrożenia oraz typu angażowanych sił i środków. Stąd efektywność i skuteczność procesu ratowniczego jest ściśle powiązana z poziomem współpracy jego systemów oraz synergią ich współdziałania. Jest to wyzwanie, któremu musi sprostać zarówno system ratownictwa w Polsce, jak i systemy funkcjonujące na świecie. $Z$ tego wyniknęła potrzeba przeprowadzenia analizy porównawczej oraz odniesienia się do jej wyników.

Artykuł ma na celu zaprezentowanie wyników analizy porównawczej istotnych elementów systemu ratownictwa w Polsce oraz innych krajów i sformułowanie na tej podstawie rekomendacji. Przeprowadzone badania zostały wykonane w ramach projektu Narodowego Centrum Badań i Rozwoju pn. „Wysokospecjalistyczna platforma wspomagająca planowanie cywilne i ratownictwo w administracji publicznej Rzeczypospolitej Polskiej oraz w jednostkach organizacyjnych Krajowego Systemu Ratowniczo-Gaśniczego"'. Zastosowane metody badawcze obejmują: przegląd literatury i wyników badań krajowych i zagranicznych, analizę danych statystycznych, analizę słabych i mocnych stron systemów ratownictwa oraz analizę modeli organizacyjnych ratownictwa wybranych krajów.

${ }^{1}$ Projekt NCBiR, umowa nr DOB-BIO7/11/02/2015. Projekt realizowany ze środków NCBiR w latach 2015-2018 przez konsorcjum Politechnika Warszawska Wydział Zarządzania oraz firma Medcore Sp. z o.o. 


\section{Analiza statystyk pożarów i wypadków drogowych w Polsce i na świecie}

Podstawą systemu ratownictwa tak w Polsce, jak i na świecie jest ochrona przeciwpożarowa oraz ratownictwo medyczne. Stąd najczęściej publikowane statystyki, stanowiące miernik efektywności tych dwóch obszarów, dotyczą występowania i konsekwencji pożarów ze względu na ocenę sprawności służb ratowniczo-gaśniczych oraz wypadków drogowych ze względu na służby ratownictwa medycznego. Poniżej przedstawiono analizę statystyk publikowanych przez International Association of Fire and Rescue Services oraz World Health Organization, które stanowią reprezentatywne źródło danych statystycznych oraz mierników oceny.

Analizując stopień zagrożenia pożarami w Polsce na tle innych krajów, należy stwierdzić, że utrzymuje się on na średnim poziomie (tabela 1). Biorąc jednak pod uwagę liczbę mieszkańców, można stwierdzić, że intensywność zagrożenia jest wysoka (liczba pożarów/1000 mieszkańców $=3,7$ ), wyższa niż w przypadku sąsiadujących z nami państw, takich jak Czechy, Ukraina czy Rosja (liczba pożarów/1000 mieszkańców $<2$ ), zbliżona natomiast do państw wysoko uprzemysłowionych, takich jak Litwa, Francja, Wielka Brytania czy USA (liczba pożarów/1000 mieszkańców > 3). Można zatem przyjąć, że liczba pożarów w Polsce odpowiada poziomowi, który jest charakterystyczny dla krajów rozwiniętych, charakteryzujących się wysoką koncentracją mieszkańców w rozbudowanych aglomeracjach miejskich.

Tabela 1. Liczba pożarów w 2014 roku

\begin{tabular}{|l|c|c|c|}
\hline \multicolumn{1}{|c|}{ Kraj } & Liczba pożarów & $\begin{array}{c}\text { Liczba } \\
\text { mieszkańców } \\
\text { (w tys.) }\end{array}$ & $\begin{array}{c}\text { Liczba pożarów } \\
\text { na 1000 mieszkańców }\end{array}$ \\
\hline USA & 1298000 & 318907 & 4,1 \\
\hline Francja & 270900 & 66030 & 4,1 \\
\hline Wielka Brytania & 212500 & 61370 & 3,5 \\
\hline Niemcy & 197393 & 82218 & 2,4 \\
\hline Rosja & 150437 & 144000 & 1,0 \\
\hline Polska & 145237 & 39492 & 3,7 \\
\hline Ukraina & 68879 & 43001 & 1,6 \\
\hline Węgry & 19536 & 9877 & 2,0 \\
\hline Czechy & 17388 & 10505 & 1,7 \\
\hline Litwa & 13324 & 2943 & 4,5 \\
\hline
\end{tabular}

Źródło: opracowanie własne na podstawie [CTIF 2016, s. 24]. 
Polska zajmuje również wysoką pozycję pod względem liczby wypadków ze skutkiem śmiertelnym podczas pożarów (tabela 2).

Tabela 2. Charakterystyka skutków pożarów w 2014 roku

\begin{tabular}{|l|c|c|c|c|c|c|}
\hline \multirow{2}{*}{ Kraj } & \multicolumn{3}{|c|}{ Ofiary śmiertelne } & \multicolumn{3}{c|}{ Ranni } \\
\cline { 2 - 7 } & liczba & $\begin{array}{c}\text { liczba } \\
\text { na 100 tys. } \\
\text { mieszkańców }\end{array}$ & $\begin{array}{c}\text { liczba na } 100 \\
\text { pożarów }\end{array}$ & liczba & $\begin{array}{c}\text { liczba } \\
\text { na 100 tys. } \\
\text { mieszkańców }\end{array}$ & $\begin{array}{c}\text { liczba na } 100 \\
\text { pożarów }\end{array}$ \\
\hline Rosja & 10068 & 7,0 & 6,7 & 10951 & 7,6 & 7,3 \\
\hline USA & 3275 & 1,0 & 0,3 & 15775 & 4,9 & 1,2 \\
\hline Ukraina & 2246 & 5,2 & 3,3 & 1450 & 3,4 & 2,1 \\
\hline Polska & 493 & 1,2 & 0,3 & - & - & - \\
\hline Niemcy & 375 & 0,5 & 0,2 & - & - & - \\
\hline Wielka & 322 & 0,5 & 0,2 & 9748 & 15,9 & 4,6 \\
Brytania & 280 & 0,4 & 0,1 & 13703 & 20,8 & 5,1 \\
\hline Francja & 125 & 4,2 & 0,9 & 193 & 6,6 & 1,4 \\
\hline Litwa & 114 & 1,1 & 0,7 & 1179 & 11,2 & 6,8 \\
\hline Czechy & 94 & 1,0 & 0,5 & 729 & 7,4 & 3,7 \\
\hline Węgry & & & & & & - \\
\hline
\end{tabular}

Źródło: opracowanie własne na podstawie [CTIF 2016, s. 24].

Tabela 3. Liczba strażaków w 2014 roku

\begin{tabular}{|c|c|c|c|c|}
\hline \multirow{2}{*}{ Kraj } & \multicolumn{2}{|c|}{ Liczba strażaków } & \multirow{2}{*}{$\begin{array}{l}\text { Liczba strażaków } \\
\text { zawodowych } \\
\text { na } 100 \text { tys. } \\
\text { mieszkańców }\end{array}$} & \multirow{2}{*}{$\begin{array}{l}\text { Liczba strażaków } \\
\text { ochotników } \\
\text { na } 100 \text { tys. } \\
\text { mieszkańców }\end{array}$} \\
\hline & zawodowych & ochotników & & \\
\hline Rosja & 370000 & 150900 & 257 & 105 \\
\hline Ukraina & 55241 & 156664 & 128 & 364 \\
\hline Czechy & 12161 & 71053 & 116 & 676 \\
\hline Węgry & 11169 & 17784 & 113 & 180 \\
\hline USA & 354600 & 786150 & 111 & 247 \\
\hline Litwa & 2951 & - & 100 & - \\
\hline Francja & 53100 & 193800 & 80 & 294 \\
\hline Polska & 30154 & 262512 & 76 & 665 \\
\hline $\begin{array}{l}\text { Wielka } \\
\text { Brytania }\end{array}$ & 40100 & 1400 & 65 & 2 \\
\hline Niemcy & 44574 & 1023345 & 55 & 1267 \\
\hline
\end{tabular}

Źródło: opracowanie własne na podstawie [CTIF 2016, s. 32]. 
Znacznie lepiej prezentują się statystyki po uwzględnieniu ogólnej liczby mieszkańców oraz pożarów. Stopień wypadkowości podczas pożarów jest wtedy w naszym kraju porównywalny do tego, który występuje w USA, w Czechach czy na Węgrzech, chociaż nadal jest wyższy niż w Wielkiej Brytanii, w Niemczech czy we Francji.

Poziom bezpieczeństwa jest niewątpliwie związany z liczbą ratowników - strażaków zawodowych i ochotników (tabela 3). Polska należy do krajów, w których ochrona pożarowa oparta jest głównie na ochotniczej straży pożarnej. Zajmuje czołowe miejsce pod względem liczby ochotników przypadającej na 100 tys. mieszkańców. Wyższą wartość tego wskaźnika osiągają jedynie Niemcy oraz Czechy. Liczba strażaków zawodowych w naszym kraju nie przekracza 100 na 100 tys. mieszkańców. Podobnie jest we Francji, Niemczech i Wielkiej Brytanii, a jednak liczba wypadków śmiertelnych jest tam znacznie niższa.

Analiza stanu wyposażenia zespołów straży pożarnej również nie prowadzi do prostych wniosków (tabela 4).

Tabela 4. Liczba siedzib i wyposażenia strażaków w 2014 roku

\begin{tabular}{|c|c|c|c|c|c|c|c|}
\hline \multirow{3}{*}{ Kraj } & \multirow{3}{*}{$\begin{array}{c}\text { Liczba } \\
\text { zgonów } \\
\text { na } 100 \text { tys. } \\
\text { mieszkań- } \\
\text { ców }\end{array}$} & \multirow{2}{*}{\multicolumn{2}{|c|}{ Liczba siedzib }} & \multicolumn{4}{|c|}{ Liczba samochodów } \\
\hline & & & & \multicolumn{2}{|c|}{ ratowniczo-gaśniczych } & \multicolumn{2}{|c|}{ z drabiną mechaniczną } \\
\hline & & razem & $\begin{array}{c}\text { na } 100 \text { tys. } \\
\text { miesz- } \\
\text { kańców }\end{array}$ & razem & $\begin{array}{c}\text { na } 100 \text { tys. } \\
\text { miesz- } \\
\text { kańców }\end{array}$ & razem & $\begin{array}{c}\text { na } 100 \text { tys. } \\
\text { miesz- } \\
\text { kańców }\end{array}$ \\
\hline Francja & 0,4 & 7296 & 11,0 & 8533 & 12,9 & 1221 & 1,8 \\
\hline Niemcy & 0,5 & 33460 & 41,4 & 2414 & 3,0 & 44574 & 55,2 \\
\hline $\begin{array}{l}\text { Wielka } \\
\text { Brytania }\end{array}$ & 0,5 & 2053 & 3,3 & 235 & 0,4 & 40100 & 65,3 \\
\hline USA & 1,0 & 55150 & 17,3 & 69150 & 21,7 & 7000 & 2,2 \\
\hline Węgry & 1,0 & 243 & 2,5 & 992 & 10,0 & 102 & 1,0 \\
\hline Czechy & 1,1 & 10505 & 100,0 & 3870 & 36,8 & 340 & 3,2 \\
\hline Polska & 1,2 & 16907 & 42,8 & 19447 & 49,2 & 717 & 1,8 \\
\hline Litwa & 4,2 & 2943 & 100,0 & 259 & 8,8 & 51 & 1,7 \\
\hline Ukraina & 5,2 & 894 & 2,1 & 3601 & 8,4 & 334 & 0,8 \\
\hline Rosja & 7,0 & 47026 & 32,7 & 17100 & 11,9 & 1600 & 1,1 \\
\hline
\end{tabular}

Źródło: opracowanie własne na podstawie [CTIF 2016, s. 32].

Jeśli chodzi o stan wyposażenia, od krajów charakteryzujących się wyższym stopniem bezpieczeństwa różni nas wyraźnie wyposażenie w samochody. Liczba 
samochodów z drabinami mechanicznymi przypadająca na 100 tys. mieszkańców jest jedną z najniższych (1,8/100 tys. mieszkańców) i jest wielokrotnie niższa od wskaźnika dla Niemiec (55,2/100 tys. mieszkańców) czy Wielkiej Brytanii (65,3/100 tys. mieszkańców).

Jeśli chodzi o wypadki drogowe, ich liczbę bezwzględną oraz liczbę na 100 tys. mieszkańców, Polska nie odbiega od średniego poziomu ustalonego dla badanych krajów (tabela 5). Niepokoi jednak bardzo wysoki wskaźnik wypadków drogowych ze skutkiem śmiertelnym, który jest jednym z najwyższych w Europie (9 osób/100 tys. mieszkańców). Wyprzedzają nas pod tym względem tylko wschodni sąsiedzi (Ukraina 12 osób/100 tys. mieszkańców, Rosja 19 osób/100 tys. mieszkańców). W rankingu tym zwracają uwagę takie kraje jak Wielka Brytania, Niemcy i Francja, dla których wspomniany wskaźnik jest najniższy.

Tabela 5. Liczba wypadków drogowych w 2013 roku

\begin{tabular}{|l|c|c|c|c|}
\hline \multirow{2}{*}{ Kraj } & \multicolumn{2}{|c|}{ Liczba wypadków } & \multicolumn{2}{c|}{ Liczba zgonów } \\
\cline { 2 - 5 } & razem & $\begin{array}{c}\text { na 100 tys. } \\
\text { mieszkańców }\end{array}$ & razem & $\begin{array}{c}\text { na 100 tys. } \\
\text { mieszkańców }\end{array}$ \\
\hline Rosja & - & 0 & 27025 & 19 \\
\hline Ukraina & - & 0 & 5099 & 12 \\
\hline USA & - & 0 & 34064 & 11 \\
\hline Litwa & 3418 & 116 & 256 & 9 \\
\hline Polska & 35847 & 91 & 3357 & 9 \\
\hline Czechy & 20342 & 194 & 655 & 6 \\
\hline Węgry & 15691 & 159 & 591 & 6 \\
\hline Francja & 56812 & 86 & 3268 & 5 \\
\hline Niemcy & 291105 & 360 & 3339 & 3 \\
\hline Wielka Brytania & 144480 & 235 & 1770 & 4 \\
\hline
\end{tabular}

Źródło: opracowanie własne na podstawie [ERSO 2015, s. 7-10].

Analizując powyższe statystyki, należy stwierdzić, że Polska należy do krajów, w których charakterystyka pożarów oraz wypadków drogowych (ich liczba oraz intensywność) jest zbliżona do krajów wysoko rozwiniętych. Niestety poziom bezpieczeństwa podczas tych zdarzeń jest dużo niższy niż w tych krajach. Dlatego też modele systemów ratownictwa wybranych krajów powinny stanowić obszar badań i rekomendacji dla polskiego modelu. Ze względu na podobieństwo funkcjonowania oraz członkostwo w Unii Europejskiej do analizy modeli ratownictwa wytypowano Niemcy, Wielką Brytanię i Francję. 


\section{Analiza SWOT polskiego systemu ratownictwa}

Przedstawiona powyżej analiza statystyk stanowi podstawę oceny polskiego systemu ratownictwa $\mathrm{w}$ porównaniu z systemami innych krajów. Prezentowana w tym miejscu analiza SWOT pokazuje, jak ta ogólna ocena jest uzasadniana i uszczegóławiana przez podmioty odpowiedzialne za organizację i realizację krajowego procesu ratowniczego.

Analiza SWOT funkcjonowania systemu ratownictwa jest prowadzona i publikowana cyklicznie, zarówno przez lokalne jednostki administracji publicznej, jak i przez organizacje odpowiedzialne za realizację procesu ratowniczego. Dokonanie przeglądu tych publikacji pozwala na sformułowanie oceny wewnętrznej słabych i mocnych stron polskiego systemu ratownictwa (tabela 6) oraz oceny zewnętrznej szans i zagrożeń, które powstają na skutek oddziaływania otoczenia na ten system (tabela 7).

Tabela 6 . Mocne i słabe strony polskiego systemu ratownictwa

\begin{tabular}{|l|l|l|}
\hline Wyszczególnienie & \multicolumn{1}{|c|}{ Mocne strony } & \multicolumn{1}{|c|}{ Słabe strony } \\
\hline Ocena ogólna & Sprawne funkcjonowanie & $\begin{array}{l}\text { Nieadekwatne środki finansowe } \\
\text { w stosunku do realizowanych zadań } \\
\text { ratowniczych }\end{array}$ \\
\hline $\begin{array}{l}\text { Ocena funkcjono- } \\
\text { wania }\end{array}$ & $\begin{array}{l}\text { Zoptymalizowana sieć rozmieszcze- } \\
\text { nia jednostek ratowniczych }\end{array}$ & $\begin{array}{l}\text { Przeciążenie zadaniami w stosunku } \\
\text { do posiadanego stanu osobowego, } \\
\text { zwłaszcza w obszarze kontrolno- } \\
\text {-rozpoznawczym, szkoleniowym } \\
\text { i logistycznym }\end{array}$ \\
\hline $\begin{array}{l}\text { Prestiż i ranga } \\
\text { społeczna }\end{array}$ & $\begin{array}{l}\text { Duże zaufanie społeczne i wysoki } \\
\text { prestiż zawodu ratownika }\end{array}$ & $\begin{array}{l}\text { Problemy w pozyskaniu nowej } \\
\text { kadry zespołów ratowniczych }\end{array}$ \\
\hline $\begin{array}{l}\text { Sprawność działań } \\
\text { prewencyjnych } \\
\text { lokalnych }\end{array}$ & $\begin{array}{l}\text { Przeprowadzanie cyklicznych } \\
\text { i systematycznych czynności kon- } \\
\text { trolno-rozpoznawczych w obiektach } \\
\text { o wysokim stopniu zagrożenia }\end{array}$ & $\begin{array}{l}\text { Nieoptymalne wykorzystanie zaso- } \\
\text { bów kontrolno-rozpoznawczych na } \\
\text { potrzeby działalności ratowniczej } \\
\text { i planowania operacyjnego }\end{array}$ \\
\hline $\begin{array}{l}\text { Sprawność reago- } \\
\text { wania }\end{array}$ & $\begin{array}{l}\text { Wysoka mobilność i zdolność do } \\
\text { szybkiego reagowania na pojawia- } \\
\text { jące się nowe zagrożenia }\end{array}$ & $\begin{array}{l}\text { Brak lokalnych centrów powia- } \\
\text { damiania ratunkowego i obsługa } \\
\text { nr 112 przez dyspozytornie pogoto- } \\
\text { wia ratunkowego }\end{array}$ \\
\hline $\begin{array}{l}\text { Sprawność współ- } \\
\text { działania }\end{array}$ & $\begin{array}{l}\text { Możliwość szybkiego uzyskania } \\
\text { wsparcia z poziomu centralnego } \\
\text { w ramach wojewódzkich odwodów } \\
\text { operacyjnych }\end{array}$ & $\begin{array}{l}\text { Brak informacji o codziennej goto- } \\
\text { wości operacyjnej (bojowej) innych } \\
\text { podmiotów ratowniczych tworzą- } \\
\text { cych system ratowniczy }\end{array}$ \\
\hline
\end{tabular}


cd. tabeli 6

\begin{tabular}{|c|c|c|}
\hline Wyszczególnienie & Mocne strony & Słabe strony \\
\hline $\begin{array}{l}\text { Integracja sił } \\
\text { i środków }\end{array}$ & $\begin{array}{l}\text { Efektywne wspomaganie i koor- } \\
\text { dynacja działań ratowniczych dla } \\
\text { zdarzeń wykraczających poza moż- } \\
\text { liwości lokalnych sił ratowniczych }\end{array}$ & $\begin{array}{l}\text { Brak zintegrowanego stanowiska } \\
\text { kierowania na potrzeby służb ratow- } \\
\text { niczych }\end{array}$ \\
\hline $\begin{array}{l}\text { Infrastruktura } \\
\text { i wyposażenie }\end{array}$ & $\begin{array}{l}\text { Wyposażone w coraz nowocześniej- } \\
\text { szy sprzęt jednostki ratownicze }\end{array}$ & $\begin{array}{l}\text { Niewystarczające zaplecze sprzę- } \\
\text { towe dla jednostek ratowniczych } \\
\text { oraz braki w wyposażeniu jednostek } \\
\text { specjalistycznych }\end{array}$ \\
\hline Technologia & $\begin{array}{l}\text { Stałe wprowadzanie nowych tech- } \\
\text { nologii }\end{array}$ & $\begin{array}{l}\text { Brak systemu teleinformatycznego } \\
\text { wspomagającego dowodzenie, } \\
\text { zintegrowanego z systemami telein- } \\
\text { formatycznymi innych podmiotów } \\
\text { współpracujących }\end{array}$ \\
\hline Kształcenie kadry & $\begin{array}{l}\text { Funkcjonujący system kształcenia } \\
\text { i doskonalenia zawodowego kadry } \\
\text { Wysoka gotowość funkcjonariuszy } \\
\text { i pracowników do podnoszenia } \\
\text { poziomu wykształcenia ogólnego } \\
\text { i kwalifikacji zawodowych }\end{array}$ & $\begin{array}{l}\text { Brak systemu szkolenia i doskonale- } \\
\text { nia w zakresie pracy dyspozytorów }\end{array}$ \\
\hline Rozwój kadry & $\begin{array}{l}\text { Wysoko wykwalifikowana kadra } \\
\text { zajmująca stanowiska dowódcze }\end{array}$ & $\begin{array}{l}\text { Brak modelu systemu motywacyj- } \\
\text { nego pozwalającego optymalnie } \\
\text { wykorzystać posiadane zasoby } \\
\text { kadrowe }\end{array}$ \\
\hline $\begin{array}{l}\text { Współpraca mię- } \\
\text { dzynarodowa }\end{array}$ & $\begin{array}{l}\text { Aktywność i współpraca między- } \\
\text { narodowa w zakresie ratownictwa } \\
\text { i działalności prewencyjnej }\end{array}$ & - \\
\hline
\end{tabular}

Źródło: opracowanie własne.

Tabela 7. Szanse i zagrożenia polskiego systemu ratownictwa

\begin{tabular}{|l|l|l|}
\hline \multicolumn{1}{|c|}{ Wyszczególnienie } & \multicolumn{1}{|c|}{ Szanse } & \multicolumn{1}{|c|}{ Zagrożenia } \\
\hline $\begin{array}{l}\text { Sytuacja społeczno-gospo- } \\
\text { darcza }\end{array}$ & $\begin{array}{l}\text { Regionalny rozwój i wzrost } \\
\text { gospodarczy }\end{array}$ & $\begin{array}{l}\text { Ubożenie przedsiębiorstw oraz } \\
\text { lekceważenie zagrożeń, powo- } \\
\text { dujące ograniczanie kosztów } \\
\text { utrzymania i konserwacji instalacji } \\
\text { oraz zabezpieczeń }\end{array}$ \\
\hline Sytuacja ekonomiczna & $\begin{array}{l}\text { Możliwość wykorzystania } \\
\text { środków z funduszy struk- } \\
\text { turalnych unii europejskiej } \\
\text { i innych funduszy pomoco- } \\
\text { wych }\end{array}$ & $\begin{array}{l}\text { Ograniczenia budżetu państwa } \\
\text { i związane z tą sytuacją niewy- } \\
\text { starczające środki finansowe na } \\
\text { realizację zadań ustawowych }\end{array}$ \\
\hline
\end{tabular}


cd. tabeli 6

\begin{tabular}{|c|c|c|}
\hline Wyszczególnienie & Szanse & Zagrożenia \\
\hline Sytuacja na rynku pracy & $\begin{array}{l}\text { Rosnąca ranga problematyki } \\
\text { bezpieczeństwa w ramach } \\
\text { zrównoważonego rozwoju } \\
\text { społeczno-gospodarczego }\end{array}$ & $\begin{array}{l}\text { Spadek atrakcyjności pracy } \\
\text { i służby w jednostkach ratowni- } \\
\text { czych w stosunku do krajowego } \\
\text { rynku pracy }\end{array}$ \\
\hline $\begin{array}{l}\text { Potrzeby społeczne zwią- } \\
\text { zane z ochroną i ratownic- } \\
\text { twem }\end{array}$ & $\begin{array}{l}\text { Uzyskanie zgody na zatrudnie- } \\
\text { nie większej liczby ratowników }\end{array}$ & $\begin{array}{l}\text { Stale rosnąca liczba obiektów } \\
\text { przewidzianych do kontroli oraz } \\
\text { coraz szerszy zakres przeprowa- } \\
\text { dzanych czynności kontrolnych } \\
\text { przy niewystarczającej liczbie osób } \\
\text { sprawujących ochronę }\end{array}$ \\
\hline $\begin{array}{l}\text { Działania i decyzje admini- } \\
\text { stracji publicznej w zakre- } \\
\text { sie integracji systemów } \\
\text { ratownictwa }\end{array}$ & $\begin{array}{l}\text { Perspektywa budowy zintegro- } \\
\text { wanego systemu ratownictwa } \\
\text { i ochrony ludności }\end{array}$ & $\begin{array}{l}\text { Brak uregulowań prawnych inte- } \\
\text { grujących autonomiczne systemy } \\
\text { ratownicze oraz brak jednolitych } \\
\text { procedur ratowniczych i zasad } \\
\text { współdziałania służb i podmiotów } \\
\text { ratowniczych }\end{array}$ \\
\hline $\begin{array}{l}\text { Działania i decyzje admini- } \\
\text { stracji publicznej w zakre- } \\
\text { sie rozwoju systemu powia- } \\
\text { damiania ratunkowego }\end{array}$ & $\begin{array}{l}\text { Uzyskanie zgody na organi- } \\
\text { zację systemu powiadamiania } \\
\text { ratunkowego w powiatach } \\
\text { i gminach }\end{array}$ & $\begin{array}{l}\text { Występowanie zawirowań orga- } \\
\text { nizacyjno-prawnych związanych } \\
\text { z wdrożeniem przepisów prawa } \\
\text { o krajowym systemie ratowniczym } \\
\text { (ksr) i innych obszarach związa- } \\
\text { nych z ratownictwem (np. nr 112) }\end{array}$ \\
\hline $\begin{array}{l}\text { Działania i decyzje admini- } \\
\text { stracji publicznej w zakre- } \\
\text { sie organizacji i rozwoju } \\
\text { systemu ratownictwa }\end{array}$ & $\begin{array}{l}\text { Aktywne włączanie się jedno- } \\
\text { stek administracji publicznej } \\
\text { do rozwiązywania problemów } \\
\text { związanych z ratownictwem }\end{array}$ & $\begin{array}{l}\text { Odpływ kadry związany z plano- } \\
\text { wanymi niekorzystnymi zmianami } \\
\text { przepisów, np. Emerytalnych }\end{array}$ \\
\hline $\begin{array}{l}\text { Integracja i współpraca } \\
\text { różnych typów służb } \\
\text { ratowniczych }\end{array}$ & $\begin{array}{l}\text { Lepsza współpraca oraz inte- } \\
\text { gracja stanowisk kierowania } \\
\text { pogotowia ratunkowego, straży } \\
\text { pożarnej i powiatowego cen- } \\
\text { trum zarządzania kryzysowego } \\
\text { na poziomie powiatu i gminy }\end{array}$ & $\begin{array}{l}\text { Ograniczona współpraca pod- } \\
\text { miotów odpowiedzialnych za } \\
\text { świadczenie usług ratowniczych } \\
\text { skutkująca trudnościami w realiza- } \\
\text { cji zadań ratowniczych }\end{array}$ \\
\hline Wpływ technologii i nauki & $\begin{array}{l}\text { Możliwość wykorzystania } \\
\text { rozwijających się nowo- } \\
\text { czesnych metod nauczania, } \\
\text { np. e-learningu }\end{array}$ & - \\
\hline
\end{tabular}

Źródło: opracowanie własne.

Wyniki powyższej analizy wskazują jednoznacznie, że warto sięgnąć po sprawdzone w innych krajach wzorce, by wykorzystać je do rozwiązania bieżących problemów, ale także by zoptymalizować wprowadzane w krajowym systemie ratownictwa zmiany. 


\section{Wybrane modele systemów ratownictwa i ochrony przeciwpożarowej}

Zróżnicowane podejścia do modelowania systemu ochrony przeciwpożarowej powodują, że powstają różne wzorce, które można wykorzystywać jako zbiory dobrych i sprawdzonych praktyk. Poniższe przykłady nie wyczerpują możliwości w tym zakresie, ale są reprezentatywne dla rekomendacji przygotowywanych w odniesieniu do systemu krajowego.

\section{Model niemiecki}

Straż pożarna w Niemczech opiera się głównie na formacjach zawodowych oraz ochotniczych. Zasady ich organizacji i funkcjonowania są zróżnicowane w poszczególnych krajach związkowych (zwanych landami) i wynikają z regionalnych przepisów prawnych. Nie ma to jednak wpływu na skuteczność funkcjonowania. Niemiecką ochronę przeciwpożarową cechują i wyróżniają na tle innych państw Unii Europejskiej ciągła kontrola, analiza i weryfikacja przyjętych rozwiązań (stosowanych metod i procedur ratowniczych) i prowadzenie systematycznego doskonalenia na podstawie uzyskanych wyników [Zboina, Wojtasiak i Mazur 2015, s. 13].

Jednostki zawodowej straży pożarnej tworzone są w miastach powyżej 80 tys. mieszkańców. W mniejszych miejscowościach ochronę pełnią ochotnicze straże pożarne. Nadzór nad nimi sprawuje ministerstwo spraw wewnętrznych danego landu. Profil jednostek zawodowych straży pożarnych, tj. gaśniczy lub ratowniczo-gaśniczy, wynika z miejscowej specyfiki zagrożeń oraz wskaźnikowej oceny zagrożeń. Wskaźniki ustalane są na podstawie analizy zagrożeń. Pod uwagę brana jest wielkość miasta, liczba i rodzaj zagrożeń pożarowych, topografia, oceny taktyczne oraz możliwość dysponowania siłami. Liczba i lokalizacja jednostek wynikają z kryterium czasu. Czas od otrzymania zgłoszenia do rozpoczęcia udzielania pomocy wynosi do 10 minut - 1,5 minuty jest przewidziane na przyjęcie zgłoszenia i ogłoszenie alarmu, a 8 minut na dojazd do miejsca zdarzenia.

Dla ochotniczych straży pożarnych analogiczne wymagania wynoszą: czas od przyjęcia zgłoszenia do wyjazdu - 5 minut (w tym 4 minuty na przyjęcie zgłoszenia i 1 minuta na rozpoznanie), czas dojazdu - 10 minut. Czas zmienia się w zależności od możliwości i specyfiki danej jednostki. Obowiązek zapewnienia ochrony przeciwpożarowej oraz zabezpieczenia sił i środków do likwidacji miejscowych zagrożeń spoczywa na gminach. Organizują one jednostki ochotniczych straży pożarnych, które mają status gminnych instytucji publicznych. 


\section{Model angielski}

Organizację i funkcjonowanie służb ratowniczych Wielkiej Brytanii cechuje zróżnicowanie terytorialne w odniesieniu do Anglii, Irlandii Północnej, Szkocji i Walii. W Anglii władzę centralną nad służbami ratowniczymi sprawuje Ministerstwo ds. Społeczności i Samorządów Lokalnych. Służby ratownicze tworzone są na kilku poziomach organizacyjnych: centralnym i regionalnym, hrabstw metropolitarnych i niemetropolitarnych. Podmiotem nadrzędnym, który nadzoruje władze jednostek straży pożarnych, podejmuje większość decyzji i odpowiada za bezpieczeństwo publiczne, jest sekretarz stanu [Zboina, Wojtasiak i Mazur 2015, s. 16-19].

Charakterystyczny jest brak podziału na straż państwową i ochotniczą. Istnieje natomiast podział na strażaków rezerwowych, ich liczba wynosi ok. 17 tys., i strażaków zawodowych, których liczba przekracza 44 tys. Obie grupy są podobnie wyszkolone i wyposażone. Odmienny jest zakres godzin pracy i wynagrodzenia. Strażacy zawodowi pełnią służbę w jednostkach w systemie zmianowym [Kowalczyk i in. 2015, s. 41-42].

Wydawane są i aktualizowane wytyczne dotyczące grup katastrof i zdarzeń, dla których zdefiniowano schematy postępowania przeznaczone do stosowania wprost przy uwzględnieniu okoliczności danego zdarzenia. Podlegają one bieżącej weryfikacji, przykładowo wytyczne dla służb ratowniczych są aktualizowane co trzy lata.

\section{Model francuski}

We Francji wyróżnia się dwie kategorie strażaków - militarnych (5\%) oraz cywilnych (95\%). Paryż i Marsylia chronione są przez formacje militarne, pozostały obszar Francji podlega ochronie cywilnej. Wśród pracowników cywilnych wyróżnia się ochotników (80\% wszystkich strażaków) oraz zawodową straż pożarną (15\% wszystkich strażaków) [Zboina, Wojtasiak i Mazur 2015, s. 19-22].

Służba ochrony pożarniczej i ratowniczej podlega Ministerstwu Spraw Wewnętrznych, a konkretnie Generalnej Dyrekcji Ochrony Cywilnej i Zarządzania Kryzysowego. Jest zorganizowana z wydzieleniem trzech podstawowych poziomów: gminy, departamentu (odpowiednik województwa w Polsce) oraz kraju. Poziom gminy odpowiada za doraźne i bieżące interwencje. Zarządzanie operacyjne jest realizowane na poziomie departamentu. Na tym poziomie prowadzone są również analizy oraz dokonywany jest podział środków budżetowych. Zarządzanie kryzysowe w obliczu katastrof i poważnych zagrożeń naturalnych jest zapewniane na poziomie kraju.

Model francuski wykorzystuje specjalne rozwiązania ochrony przeciwpożarowej. Należą do nich np. kontrolowane wypalania oraz patrolowanie rejonów 
zagrożonych. Stosowane metody są poddawane cyklicznej weryfikacji i okresowo dostosowywane do zmieniających się warunków oraz potrzeb.

\section{Wybrane modele systemów ratownictwa medycznego}

$\mathrm{Na}$ świecie wyróżnia się dwa podstawowe wzorce systemów ratownictwa medycznego - są to modele anglo-amerykański oraz francusko-niemiecki [Bem 2015]. Wspólną cechą obu systemów jest zapewnienie szybkiej i efektywnej pomocy, niezbędnej w stanach zagrożenia zdrowia i życia, wypadkach oraz katastrofach. Różnice dotyczą intensywności wykorzystania podstawowych i zaawansowanych zabiegów ratujących życie na miejscu zdarzenia oraz kwalifikacji i uprawnień zespołów ratowniczych.

\section{Model anglo-amerykański}

Model anglo-amerykański opiera się na zasadzie ,bierz i jedź”. W Stanach Zjednoczonych system ratownictwa medycznego określa się nawet jako zorganizowany system stworzony do transportu chorych i poszkodowanych pacjentów do szpitala [Kosydar-Bochenek i in. 2012, s. 72]. Nadrzędnym celem modelu jest jak najszybsze przetransportowanie pacjenta na oddział ratunkowy i ograniczenie do minimum przedszpitalnych interwencji na miejscu zdarzenia. Dlatego w Stanach Zjednoczonych i Wielkiej Brytanii w zespołach wyjazdowych dyżury pełnią ratownicy medyczni z licencją i ukończoną odpowiednią szkołą, którzy uprawnieni są do wykonywania większości czynności ratowniczych bez udziału lekarza.

W USA paramedyków określa się mianem zastępców lekarzy w świadczeniu pomocy przedszpitalnej. W amerykańskim systemie wyróżnia się cztery poziomy wykształcenia ratowników, z których najważniejsi są wykwalifikowani ratownicy medyczni - paramedycy. Mogą oni wykonywać wiele zaawansowanych czynności, włącznie z wkłuciem dożylnym, podawaniem wybranych leków, intubacją, konikotomią i defibrylacją. W przypadku problemów lub wątpliwości porozumiewają się z lekarzem dyżurnym, koordynatorem ds. ratownictwa. Lekarz ratunkowy ma bezpośredni kontakt z pacjentem dopiero w szpitalnym oddziale ratunkowym.

\section{Model francusko-niemiecki}

Mottem francusko-niemieckiego modelu ratownictwa medycznego stało się stwierdzenie niemieckiego chirurga, M. Kirschnera, że to nie poszkodowany powinien przychodzić do lekarza, ale lekarz do poszkodowanego. Stąd w systemie francusko-niemieckim główna rola przypada lekarzowi, osobie 
o odpowiednich kwalifikacjach zawodowych i wiedzy [Kosydar-Bochenek i in. 2012, s. 71].

System francusko-niemiecki nie wyróżnia medycyny ratunkowej jako odrębnej specjalności medycznej. Pomocy osobom poszkodowanym udzielają lekarze różnych specjalności, najczęściej anestezjolodzy i chirurdzy. Lekarzowi towarzyszą sanitariusz lub ratownik medyczny o ograniczonych kompetencjach medycznych, którzy pomagają mu i asystują.

Przesłaniem tego modelu ratownictwa jest ogólna zasada medycyny ratunkowej: „zostań i ratuj, działaj, stabilizuj pacjenta, lecz”. Zgodnie z nią należy przywrócić podstawowe czynności życiowe i ustabilizować stan ogólny pacjenta już na miejscu zdarzenia, nie czekając na przewiezienie go na oddział ratunkowy.

Lekarz już na miejscu zdarzenia po wstępnej diagnozie kwalifikuje chorego na leczenie lub dalszą diagnostykę na odpowiednim oddziale szpitalnym. Dzięki temu pacjenci transportowani są często bezpośrednio na docelowy oddział szpitalny, z pominięciem szpitalnej izby przyjęć. W uzasadnionych przypadkach, kiedy dojazd karetki na miejsce zdarzenia może zająć zbyt wiele czasu, stosowane są również śmigłowce ratunkowe. Jest to dość powszechnie przyjęta forma transportu poszkodowanych w modelu francusko-niemieckim.

\section{Podsumowanie}

Z przedstawionej analizy statystyk wynika jednoznacznie, że potrzebna jest poprawa skuteczności funkcjonowania krajowego systemu ratownictwa w zakresie bezpieczeństwa i minimalizowania wypadków ze skutkiem śmiertelnym. Praktyka innych krajów Europy Zachodniej o podobnej intensywności pożarów i wypadków drogowych pokazuje, że jest to możliwe.

Jednostki realizujące oraz nadzorujące proces ratowniczy w Polsce jako najważniejsze przyczyny niedomagania systemu wskazują:

- niewystarczający poziom współpracy oraz brak właściwego przepływu informacji pomiędzy różnymi podmiotami zaangażowanymi w proces ratowniczy,

- nieoptymalne wykorzystanie zasobów kontrolno-rozpoznawczych na potrzeby działalności ratowniczej i planowania operacyjnego,

- niewystarczające zaplecze sprzętowe dla jednostek ratowniczych oraz braki w wyposażeniu jednostek specjalistycznych,

- przeciążenie zadaniami w stosunku do posiadanego stanu osobowego, zwłaszcza w obszarze kontrolno-rozpoznawczym, szkoleniowym i logistycznym, 
- nieadekwatne zasilenie ośrodków ratownictwa w środki finansowe w stosunku do realizowanych zadań ratowniczych,

- problemy kadrowe związane zarówno z procesem kształcenia i podnoszenia kwalifikacji, jak i z pozyskiwaniem nowych ratowników,

- brak modelu systemu motywacyjnego pozwalającego optymalnie wykorzystać posiadane zasoby kadrowe.

Przeprowadzona analiza potwierdziła, że niezadowalający poziom bezpieczeństwa funkcjonowania krajowego systemu ratownictwa wynika m.in. z niewystarczającego stanu wyposażenia zespołów ratowniczych. Wskazują na to również dane statystyczne, zwłaszcza porównanie Polski z krajami Europy Zachodniej i USA (tabela 4). Kolejną kwestią są problemy kadrowe, które jednak nie wynikają z liczby zatrudnianych pracowników (tabela 3). Wynika z tego, że dogłębnej analizie należałoby poddać funkcjonowanie systemu zatrudniania, motywowania oraz rozwoju ratowników i w tych obszarach szukać możliwości zmian. Oczywiste jest niewystarczające dofinansowanie systemu ratowniczego, które trudno jest poprawić w obecnej sytuacji budżetowej. Rozwiązań należy szukać w jak najszerzej zakrojonej współpracy międzynarodowej oraz w optymalizacji wykorzystania zasobów. Konieczne jest zatem krytyczne spojrzenie na przyjęty model zarządzania krajowym systemem ratowniczym oraz podjęcie próby naśladowania i adaptacji modeli i metod sprawdzonych w złożonych organizacjach biznesowych.

Podsumowując, sformułować można następujące wnioski:

- konieczna jest lepsza integracja i współpraca zarówno na poszczególnych poziomach zarządzania administracyjnego, jak i pomiędzy różnymi jednostkami służb ratowniczych. Współpraca ta powinna być wspomagana przez organizację i budowę zintegrowanego systemu teleinformatycznego, zapewniającego płynny kontakt zespołów ratowniczych, koordynację dowodzenia oraz przepływ aktualnych informacji;

- dobrze funkcjonujący system ratowniczy wymaga odpowiedniego poziomu dofinansowania, ale w pewnym zakresie sytuację można poprawić, optymalizując wykorzystanie posiadanych i dostępnych zasobów;

- niezbędny jest krajowy program zatrudniania i rozwoju kadry ratowniczej, który powinien wykraczać poza działania jednostek lokalnych, być spójny z programami nauczania w odpowiednich typach uczelni wyższych, prowadzić do zwiększenia świadomości społecznej oraz przyjęcia modelu systemu motywacyjnego, uwzględniającego korzystne przepisy prawne dla osób zatrudnionych $\mathrm{w}$ ratownictwie.

Sprawdzone modele - niemiecki, angielski czy francuski, mogą pomóc w adaptacji rozwiązań, które poprawiają bezpieczeństwo w tych krajach. W zakresie ochrony przeciwpożarowej szczególnie warte uwagi wydają się wzorce 
niemieckie - model oparty na racjonalizacji podejmowanych działań ze względu na wyniki prowadzonych na bieżąco analiz. Słusznym podejściem w naszym systemie wydaje się zastosowanie techniki i nauki do tego, żeby optymalizować wykorzystanie zasobów.

Jeśli chodzi o ratownictwo medyczne, Polska w coraz większym zakresie adaptuje model anglo-amerykański. Należy jednak zwrócić uwagę, że zakłada on szybki i sprawny dostęp do szpitali oraz oddziałów ratunkowych, co z kolei jest warunkowane istnieniem odpowiedniej liczby miejsc przygotowanych na przyjęcie i leczenie poszkodowanych. Prowadzone w przyszłości badania powinny przynieść odpowiedź na pytanie, w jakim stopniu i przy jakich ograniczeniach krajowy system ratownictwa jest $\mathrm{w}$ stanie zaadaptować proponowane rozwiązania, by zwiększyć poziom bezpieczeństwa i komfortu obywateli.

\section{Literatura}

Bem A. [2015], Organizacja i finansowanie ratownictwa medycznego, Prace Naukowe Uniwersytetu Medycznego we Wrocławiu, nr 319, Wrocław.

CTIF [2016], Report no. 21, World Fire Statistics, http://www.ctif.org/ctif/world-fire-statistics (data dostępu: 27.08.2016).

ERSO [2015], Annual Accident Report 2015, European Commission, https:/ec.europa.eu/ transport/road_safety/specialist/statistics_en\# (data dostępu: 27.08.2016).

Kosydar-Bochenēk J., Ozga D., Szymańska J., Lewandowski B. [2012], System ratownictwa medycznego na świecie a system polski, „Zdrowie Publiczne”, nr 122(1).

Kowalczyk A., Iwańska M., Gołaszewska M., Zboina J. [2015], Analiza porównawcza wybranych zagadnień ochrony przeciwpożarowej [w:] Projektowanie systemu ratowniczego, red. J. Zboina, J. Kielin, CNBOP-PIB, Warszawa.

Ustawa z dnia 24 sierpnia 1991 r. o ochronie przeciwpożarowej, Dz.U. z 2009 r. nr 178 poz. 1380.

Ustawa z dnia 8 września 2006 r. o Państwowym Ratownictwie Medycznym, Dz.U. z 2013 r. poz. 757 ze zm.

Zboina J., Wojtasiak B., Mazur J. [2015], Organizacja ochrony przeciwpożarowej w wybranych państwach Unii Europejskiej [w:] Projektowanie systemu ratowniczego, red. J. Zboina, J. Kielin, CNBOP-PIB, Warszawa.

\section{A Comparative Analysis of Rescue System Models in Poland and Selected Countries}

(Abstract)

Rescue systems determine safety and guarantee it is provided at an adequate level. One aspect of the development of rescue systems is their continuous improvement and enrichment through the application of specialised tools and methods. Selection of these 
tools and methods should be preceded by an analysis of currently operating systems both in country and globally. This article presents solutions used outside of Poland which the authors believe could be implemented in Poland's national rescue system. They base their indication on the analysis of the national rescue systems in Poland and elsewhere.

Keywords: rescue system, model of rescue system, analysis of statistics, SWOT analysis, recommendations. 